\title{
Development of Protocol for Production of Primary Antibody against Ovalbumin Protein in Chicken for Detection of the Protein through Western Blotting
}

\author{
K.K. Kanaka ${ }^{2}$, R.N. Chatterjee ${ }^{1}$, Renu Shukla ${ }^{1}$, Pushpendra Kumar ${ }^{2}$, Bharat Bhushan ${ }^{2}$ and \\ T.K. Bhattacharya ${ }^{1 *}$ \\ ${ }^{1}$ ICAR-Directorate of Poultry Research, Rajendranagar, Hyderabad, INDIA \\ ${ }^{2}$ Animal Genetics Division, ICAR-Indian Veterinary Research Institute, Izatnagar, Bareilly, Uttar Pradesh, INDIA \\ *Correspondence author: TK Bhattacharya; E-mail: bhattacharyatk@gmail.com
}

Received: 22 Aug., 2019

Revised: 14 Oct., 2019

Accepted: 20 Oct., 2019

\begin{abstract}
Ovalbumin, a major protein of egg white plays many roles including providing nutrition to the developing embryo, acting as coagulating agent, folliculogenesis and angiogenesis in chicken and other animals. This protein is expressed mainly in magnum and then deposited over the yolk of the oocyte/zygote. Hence, it is important in formation of egg and is an essential target to measure. We cloned chicken ovalbumin CDS in pAcGFP-C1 vector and has been initially expressed in chicken primary magnum cell culture. The ovalbumin protein tagged with $6 \mathrm{x}$ Histidine was purified from cell culture and used for production of primary antibody in rat. The ovalbumin protein along with freund's adjuvant was injected to the rat, booster was given, and finally, hyper-immune sera was collected from rat. The antisera was purified for isolation of IgG. The IgG was used as primary antibody for Western blotting. Through Western blotting, ovalbumin protein isolated from chicken magnum was detected and the protocol was established to detect chicken ovalbumin protein.
\end{abstract}

Keywords: Ovalbumin, chicken, IgG, primary antibody, protocol

Ovalbumin is a member of SERPIN family and has been the major protein of the egg white in chicken. This protein is expressed mainly in magnum and has a molecular weight of $44.5 \mathrm{kDa}$ comprising of 385 amino acid residues. It is a storage protein and major source of amino acids for the developing embryo (Mine and Shahidi, 2006). Other functions of ovalbumin are; acting as factors for coagulation/ fibrinolysis cascades (D'Alessandro et al., 2010), role in folliculogenesis and angiogenesis (Mann, 2008), serving as a source of amino acid for embryo and function on developing tissues (Sugimoto et al., 1999) and playing crucial role in calcium carbonate formation and amorphous calcium carbonate stabilization i.e. biomineralization (Schwahn et al., 2008). The N-terminus of ovalbumin is acetylated and contains four sulfhydryl groups and one disul- fide bridge (Cys74-Cys121), which are inaccessible in the native state (Iametti et al., 1998). Ovalbumin secondary structure has various motifs including $\alpha$-helix $(41 \%), \beta$-sheet $(34 \%), \beta$-turns $(12 \%)$, and random coils (13\%) (Ngarize et al., 2004). The conserved reaction centre is located at Ala358- Ser359 (Stein et al., 1990) while the heterogeneous carbohydrate peptide chains contain a common core of mannose $\beta$ (1-4) glcNAc $\beta$ (1-4) glcNAc (Huntington and Stein, 2001; Guérin Dubiard et al., 2006). Types of ovalbumin protein are differentiated by the degree of phosphorylation with two, one and zero phosphorylated sites, respectively, which are located at serine residues 69 and 345 (Mine and Shahidi, 2006). Thus, activity of this protein is based on its phosphorylation sites in chicken and other animals. Detection of protein is normally accomplished by various techniques such as Western blotting or immuno-blotting and Enzyme linked immune-sorbent assay (ELISA). For detection of protein in these techniques, it is essential to have primary antibody which is detected by secondary

How to cite this article: Kanaka, K.K., Chatterjee, R.N., Shukla, R., Kumar, P., Bhushan, B. and Bhattacharya, T.K. (2019). Development of protocol for production of primary antibody against ovalbumin protein in chicken for detection of the protein through western blotting. J. Anim. Res., 9(6): 849-853. 
antibody conjugated with HRP con jugate and detection dye. In this study, we have developed protocol for production of primary antibody against chicken ovalbumin protein.

\section{MATERIALS AND METHODS}

\section{Cloning of ovalbumin cDNA}

An adult bird of IWK layer chicken line maintained at ICAR-Directorate of poultry Research, Hyderabad was sacrificed following the guidelines of Institute Animal Ethics Committee (IAEC) of the Institute. The adult birds are maintained by providing $a d l i b$ feeding and watering following standard management protocol (Chatterjee et al., 2008). The infundibulum tissue was collected and kept in $0.1 \%$ DEPC treated sterile polypropylene tube.

The total RNA was isolated from magnum tissues using Trizol (Amresco), according to the manufacturer's instruction. The magnum tissues were homogenized with $1 \mathrm{~mL}$ Trizol/50 mg of tissue and total RNA was isolated following standard protocol (Bhattacharya et al., 2011b). The concentration and purity of the RNA was determined in Genova plus Nano Drop. The RNA sample showing the OD260:280 value in between 1.9 to 2.2 was considered as good quality and was used further. The RNA sample was treated with DNaseI (Fermentas) for removal of possible genomic DNA contamination. First strand cDNA was synthesized by using Revert Aid First Strand cDNA Synthesis Kit (Thermoscientific) (Bhattacharya et al., 2012).

For amplification of whole cDNA of ovalbumin (1161 bp), a pair of primers (F: GGAT CCATG CATC ATCA CCAT CACC ACAT GGGC TCCA TCGG CGCA GCA and R: TTAA GGGG AAAC ACAT CTGC CAAA GAAG CTT) was designed by using DNASTAR software from the available ovalbumin gene sequence (NM_205152.2). The whole cDNA was amplified at $58^{\circ} \mathrm{C}$ annealing temperature and purified using gel purification kit (Qiagen).

The PCR amplified product was digested with BamHI and HindIII restriction enzymes and was cloned into an Expression vector, pAcGFP1-C1 (Clonetech) for expression of the gene following protocol of Bhattacharya et al., 2014.
The recombinant clones were transfected into the chicken myoblast primary cell culture. The myoblast cell culture was obtained following protocol of Bhattacharya et al. (2016). The recombinant DNA was transfected by electroporation in Gene Pulser Xcell ${ }^{\mathrm{TM}}$ (Biorad) following the protocol of Bhattacharya et al. (2016). Forty eight hours after transfection, the adherent cells were trypsinized and collected in sterile $15 \mathrm{ml}$ conical tube. The cells were washed with PBS and finally, mixed with cell extraction buffer (150 mM NaCl, 1\% NP-40, 0.1\% Sodium dodecyl sulphate and $50 \mathrm{mM}$ Tris, $\mathrm{pH} 8$ ) per $10^{8}$ cells. The aqueous phase containing protein was collected in a fresh tube for purification of protein. The histidine tagged protein was purified by column chromatography with His-Spin Protein Miniprep $^{\mathrm{TM}}$ following standard protocol (Divya et al., 2018)

\section{SDS-PAGE}

The $12 \%$ SDS-PAGE was prepared following standard protocol (Bhattacharya et al., 2011a) to analyse the purified protein. About $2 \mu 1$ protein was loaded in the gel and was run at $5 \mathrm{~V} / \mathrm{cm}$ of gel and the voltage was increased to $10 \mathrm{~V} / \mathrm{cm}$. The gel was stained with Coomassie brilliant blue stain and visualized.

\section{Preparation and immunization of antigen}

The purified protein was mixed with complete Freund's Adjuvant (CFA) and the mixture was injected subcutaneously on day 1 at 4 sites of the rat. A total of 3 male Wistar rats ( 2 for target and 1 as control) of 3 months age were included in immunization schedule throughout period. The detailed Immunization protocol for rat polyclonal antibody production was as shown in Table 1 . On $21^{\text {st }}$ day, blood (having raised antibodies) was collected from retro-orbital sinus/plexus of rats and serum was collected. The $\operatorname{IgG}$ was purified from the hyper-immune sera with IgG purification kit (Protein A based, GeNei ${ }^{\mathrm{TM}}$ ). The purified $\mathrm{IgG}$ was used as a primary antibody for western blotting.

\section{Western blotting}

The protein isolated from magnum tissues was run on SDS-PAGE following standard method (Bhattacharya et al., 2019). The proteins separated in SDS-PAGE were 
transferred into $0.45 \mu \mathrm{m}$ polyvinylidene fluoride (PVDF) membrane. The blotted PVDF was immersed in 3\% BSA blocking buffer with primary antibody (1:1000 dilution in TBS Tween 20) and incubated at $4{ }^{\circ} \mathrm{C}$ for overnight. The membrane was washed with the TBS Tween 20 and incubated with anti-rat IgG HRP conjugate diluted to $1: 1000$ in TBS Tween 20 buffer for 1.5 hours with constant agitation. The PVDF membrane was incubated in DAB substrate solution for 5-30 minutes until the color development. Soon after the appearance of brown color, substrate solution was drained, and the reaction was stopped by adding distilled water.

Table 1: Immunization protocol for rat polyclonal antibody production. $\mathrm{CFA}=$ Complete Freund's adjuvant; IFA= Incomplete Freund's adjuvent

\begin{tabular}{ccc}
\hline Procedure & $\begin{array}{c}\text { Protocol } \\
\text { day }\end{array}$ & Description \\
\hline $\begin{array}{c}\text { Control serum } \\
\text { collection }\end{array}$ & Day 0 & Pre-immune bleed $(0.5 \mathrm{ml}$ per rat) \\
$\begin{array}{c}\text { Primary } \\
\text { Injection }\end{array}$ & Day 1 & $\begin{array}{c}\text { Immunize with } 0.1 \mathrm{mg} \text { antigen with } \\
\text { CFAb-cutaneous injection at } 4 \\
\text { Booster } \\
\text { Injection }\end{array}$ \\
$\begin{array}{c}\text { Blood } \\
\text { collection }\end{array}$ & Day 14 & $\begin{array}{l}\text { Boost with } 50 \mu \mathrm{g} \text { antigen with IFA, } \\
\text { (sub-cutaneous injection at } 4 \text { sites) }\end{array}$ \\
\hline
\end{tabular}

\section{RESULTS AND DISCUSSION}

The first strand cDNA were synthesized from total RNA obtained from magnum part of oviductal tissue of Iwk White Leghorn chicken. A 1161 bp coding sequence of ovalbumin gene was amplified using gene specific primers. Reaction conditions as well as cycle parameters of the PCR protocol was optimized to ensure the amplification of the specific fragment with good yield. The amplified PCR products were checked in $1 \%(\mathrm{~W} / \mathrm{V})$ agarose gel electrophoresis. A single band without any non-specific amplification was noticed at the expected position on the gel.

After successful amplification and gel elution, the amplified product was subjected to restriction digestion with $\mathrm{BamHI}$ and HindIII restriction enzymes. Consequently, the ready to use inserts were cloned to pAcGFP-C1 expression vector and transformed into DH5 $\alpha$ E.coli competent cells. Then, we screened for positives colonies (Fig. 1) and positive clones were sub-cultured from which Plasmid DNA was isolated and further sequenced for confirmation of the insert.

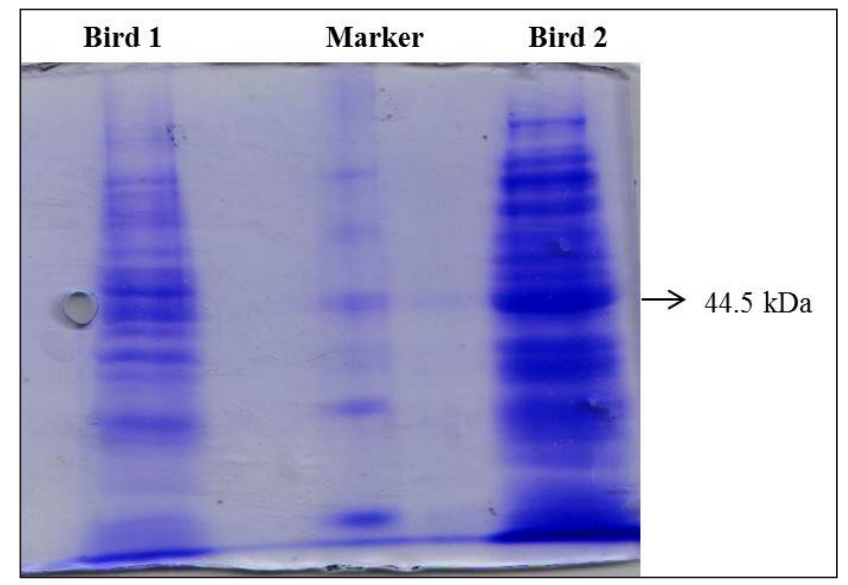

Fig. 1: SDS-PAGE analysis of magnum tissue proteins of chicken showing induced ovalbumin protein of $44.5 \mathrm{kDa}$

The 1161 bp coding sequence of ovalbumin encodes 386 amino acid residues of ovalbumin protein, which was in agreement with the findings of Ishimaru, et al. (2018). Ovalbumin protein has a molecular weight of $44.5 \mathrm{kDa}$ and is a monomeric phosphor glycoprotein with known complete amino acid sequence of 386 residues. Although it is a secretary protein, ovalbumin is lacking an N-terminal leader sequence. Transmembrane location is instead mediated by an internal sequence signal located within hydrophobic residues (Huntington and Stein, 2001).

The recombinant vector containing ovalbumin open reading frame was transfected into primary magnum cell culture by electroporation. The transfected cells were subcultured and harvested after 6 days. The crude protein was isolated from the cell lysate. The crude protein was subjected to column chromatography using His-Spin Protein Miniprep ${ }^{\mathrm{TM}}$ to purify Histidine tagged ovalbumin protein. The His-tagged protein was detected in the SDSPAGE having single band.

The purified ovalbumin protein along with Freund's adjuvant was injected into growing Wister rat on day one and booster was given on day 14 and the antibodies developed against the protein was isolated from the serum on day $21^{\text {st }}$. Blood samples (having raised antibodies) was 
collected from retro-orbital sinus/plexus of rats and serum was collected. The IgG was purified from the hyperimmune sera with IgG purification kit. The purified IgG was used as a primary antibody for western blotting to detect ovalbumin protein.

The crude protein was collected from magnum tissues. The crude protein was analysed in SDS-PAGE and proteins were separated. Then, through Western blotting, the ovalbumin protein was detected in the magnum tissues indicating the efficiency of primary anti-body developed against ovalbumin protein in chicken (Fig. 2). This primary antibody may be used to develop Western blot assay as well as ELISA assay for detection of ovalbumin protein in the tissues.

\begin{tabular}{|llll|}
\hline & Birds 1 & Bird 2 & Control \\
Ovalbumin protein $\longleftarrow$ & & & \\
& & & \\
\hline
\end{tabular}

Fig. 2: Western blot of ovalbumin protein expressed in magnum tissues of 2 birds and a control bird with muscle tissue. Magnum tissues of bird 1 and bird 2 showed presence of ovalbumin protein while muscle tissue of control bird did not show ovalbumin protein in muscle

\section{CONCLUSION}

The results revealed that the recombinant ovalbumin protein may be used to develop primary antibody against ovalbumin protein for further use to develop assay for detection of the chicken ovalbumin protein.

\section{CONFLICT OF INTEREST}

We certify that there is no conflict of interest with any financial organization regarding the material discussed in the manuscript.

\section{REFERENCES}

Bhattacharya, T.K., Chatterjee, R.N. and Priyanka, M. 2012. Polymorphisms of Pit-1 gene and its association with growth traits in chicken Poult. Sci., 91: 1057-1064.

Bhattacharya, T.K., Chatterjee, R.N., Dushyanth, K. and Shukla, R. 2014. Cloning, characterization and expression of myostatin (growth differentiating factor-8) gene in broiler and layer chicken (Gallus gallus). Mol. Biol. Rep., 42 (2): 319-327.

Bhattacharya, T.K., Chatterjee, R.N., Sharma, R.P., Niranjan, M., Rajkumar, U. and Reddy, B.L.N. 2011a. Polymorphism in prolactin promoter and their association with growth traits in chicken. Biochem. Genet., 49: 385-394.

Bhattacharya, T.K., Chatterjee, R.N., Sharma, R.P., Rajkumar, U., Niranjan, M. and Reddy, B.L.N. 2011b. Association of polymorphism in prolactin promoter and egg quality traits in layer chicken. British Poult. Sci., 52: 551-557.

Bhattacharya, T.K., Shukla, R., Chatterjee, R.N. and Bhanja, S.K. 2019. Comparative analysis of silencing expression of myostatin (MSTN) and its receptors (ACVR2A and ACVR2B) genes affecting growth traits in knock down chicken. Nat. Sci. Rep., 9(1): 7789.

Bhattacharya, T.K., Shukla, R., Chatterjee, R.N. and Dushyanth, K. 2016. Knock down of the myostatin gene by RNA interference increased body weight in chicken. J. Biotechnol., 241:61-68

Chatterjee, R.N., Sharma, R.P., Mishra, A., Dange, M. and Bhattacharya, T.K. 2008. Variability of microsatellites and their association with egg production traits in chicken. Int. $J$. Poult. Sci., 7: 77-80.

D’Alessandro, A., Righetti, P.G., Fasoli, E. and Zolla, L. 2010. The egg white and yolk interactomes as gleaned from extensive proteomic data. J. Proteom., 73 (5): 1028-1042.

Divya, D., Bhattacharya, T.K.,Gnana Prakash, M., Chatterjee, R.N., Shukla, R., Guru Vishnu, P., Vinoth, A. and Dushyanth, K. 2018. Molecular characterization and expression profiling of BMP3 gene in broiler and layer chicken. Mol. Biol. Rep., 45 (4): 477-495.

Guérin-Dubiard, C., Pasco, M., Mollé, D., Désert, C., Croguennec, T. and Nau, F. 2006. Proteomic analysis of hen egg white. J. Agric. Food Chem., 54(11): 3901-3910.

Huntington, J.A. and Stein, P.E. 2001. Structure and properties of ovalbumin. J. Chromatogr. B., 756(1): 189-198.

Iametti, S., Donnizzelli, E., Vecchio, G., Rovere, P. P., Gola, S. and Bonomi, F. 1998. Macroscopic and structural consequences of high-pressure treatment of ovalbumin solutions. J. Agric. Food Chem., 46(9): 3521-3527.

Ishimaru, T., Ito, K., Tanaka, M. and Matsudomi, N. 2018. Participation of cysteine 30 residue in the folding process of ovalbumin evaluated in a refolding experiment using cysteine mutants. Biochem. Biophys. Res. Commun., 495(1): 1061-1066.

Mann, K. 2008. Proteomic analysis of the chicken egg vitelline membrane. Proteomics, 8(11): 2322-2332. 
Mine, Y. and Shahidi, F. 2006. Chapter 1 Nutraceutical Proteins and Peptides in Health and Disease: An Overview. Nutra. Sci. Technol., 4: 3.

Ngarize, S., Adams, A. and Howell, N.K. 2004. Studies on egg albumen and whey protein interactions by FT-Raman spectroscopy and rheology. Food Hydrocoll., 18(1): 49-59.

Schwahn, V., Balz, M., Wolf, S. E., Tremel, W. and Schwahn, D. 2008. Nucleation and growth of $\mathrm{CaCO} 3$ mediated by the eggwhite protein ovalbumin: a time-resolved in situ study using small-angle neutron scattering. J. Am. Chem. Soc., 130(21): 6879-6892.
Stein, P.E., Leslie, A.G., Finch, J.T., Turnell, W.G., McLaughlin, P.J. and Carrell, R.W. 1990. Crystal structure of ovalbumin as a model for the reactive centre of serpins. Nature, 347(6288): 99-102.

Sugimoto, Y., Sanuki, S., Ohsako, S., Higashimoto, Y., Kondo, M., Kurawaki, J., Ibrahim, H.R., Aoki, T., Kusakabe, T. and Koga, K. 1999. Ovalbumin in developing chicken eggs migrates from egg white to embryonic organs while changing its conformation and thermal stability. J. Biol. Chem., 274(16): 11030-11037. 
